\title{
Cultural, Morphological and Pathogenic Characterization of Alternaria porri Causing Purple Blotch of Onion
}

\author{
Sayed Mohammad MOHSIN ${ }^{1}$, Md. Rafiqul ISLAM ${ }^{1}$, Abu Noman Faruq AHMMED ${ }^{1}$, \\ Hosna Ara Chowdhury NISHA ${ }^{1}$, Mirza HASANUZZAMAN ${ }^{2 *}$ \\ 'Sher--Bangla Agricultural University, Department of Plant Pathology, Dhaka-1207, Bangladesh \\ 2Sher-e-Bangla Agricultural University, Department of Agronomy, Dhaka-1207,Bangladesh; mhzsauag@yahoo.com ("correspondingauthor)
}

\begin{abstract}
Twenty seven (27) isolates of Alternaria porri were isolated from diseased leaf samples collected from different onion growing regions of Bangladesh and characterized for cultural, morphological and pathogenic variabilities. A. porri colonies colony colour ranged between light to dark olivacious and grayish white with irregular, regular with concentric ring and regular without concentric ring shape. Margin of colonies were entire, irregular and wavy with effuse, fluffy and velvety texture. Isolates impregnated media with colour ranged between grey to brown on the reverse of the plates. Growth rate of isolates ranged between 2.433 and $3.950 \mathrm{~mm} /$ day with fast growth in isolate DSTR 02 and least in MMBH. Morphological variation in conidia production was between $7.720 \times 10^{3}$ to $47.02 \times 10^{3}$ per $\mathrm{mm}^{2}$ with sporulation time 3.33 to 11.00 days. The conidial shape was straight to curve with light to deep brown colour. The number of horizontal and vertical separation in the conidia ranged from 3.00 to $6.00 \times 1.00$ to 2.00 with size from 11.20 to $39.20 \times 4.76$ to $11.43 \mu \mathrm{m}$. In pathogenicity test isolates also exhibited variations in size of the lesions $(2.77$ to $7.55 \mathrm{~mm}$ ) produced on onion leaves. The results demonstrate existence of considerable variation in cultural, morphological, and pathogenic characters of $A$. porri isolates prevalent in Bangladesh environment.
\end{abstract}

Keywords: Concentric ring, conidia, fungal disease, mycelium, muriform

\section{Introduction}

Onion (Allium cepa) is an important spices crop commercially grown in many countries of the world. Out of 15 important vegetables and spice crops listed by FAO, onion stands second in terms of annual world production (Ali, 2008). The crop centre of origin of onion includes Iran, Pakistan and specially their mountainous regions situated in the north of these countries (Purseglove, 1972; Islam, 2006). Besides being used as salad and vegetables, onion is generally used as spice in most of the Asian countries. Onion has great economic importance due to its medicinal and dietetic values (Chakraborty et al., 2015). Global vegetable production of nearly 36 million tons onion per annum, next to tomatoes and cabbages bears importance (FAO, 2012). The production of onion in Bangladesh is nearly 11.59 lac metric tons from 135569.69 hectares of land, whereas the demand is around 19.5 lac metric tons per year (BBS, 2012). Among the onion producing countries of the world, Korea Republic tops the list with $65.25 \mathrm{tha}^{-1}$ followed by USA (53.91 tha $\left.{ }^{-1}\right)$, Spain (52.06 t $\left.\mathrm{ha}^{-1}\right)$, and Japan $\left(47.55 \mathrm{th}^{-1}\right)(\mathrm{FAO}, 2008)$. The production of onion in Bangladesh is $8.95 \mathrm{t} \mathrm{ha}^{-1}$ (AIS, 2011) which is much lower compared to other onion producing countries. Onion suffers from 66 diseases including 10 bacterial, 38 fungal, 6 nemic, 3 viral, 1 mycoplasmal, 1 parasitic plant and 7 miscellaneous diseases and disorders (Schwartz, 2010). Purple blotch of onion is noted as a major disease throughout the world including Bangladesh which is caused by a fungus $A$. porri (Islam et al., 2001). This disease can cause 30 to $50 \%$ yield reduction (Pascua et al., 1997). About 20 to $25 \%$ seed yield reduction has also been recorded in India (Thind and Jhooty, 1982) and 41 to $44 \%$ in Bangladesh (Hossain et al., 1993). Many studies have been conducted on the management of purple blotch in onion (Ashrafuzzaman and Ahmed, 1976; Rahman et al., 1988; Rahman, 1990). Rovral 50WP (0.2\%), Dithane M-45 (0.2\%) and other fungicides are applied as foliar spray to control the disease. Most of the present day fungicides have failed in arresting the disease. This may be due to the arising genetic variability or introduction of new races of the pathogen. Variation in pathogen populations generally can be detected on the basis of morphological, cultural and pathogenic specificity. Variability studies are important to document the changes occurring in populations and individuals as variability in morphological and physiological traits indicate the existence of different 
pathotypes. Variability is a well known phenomenon in genus Alternaria and may be noticed as changes in spore shape and size, growth and sporulation, pathogenicity, etc. The present study was undertaken to identify and characterize $A$. porri isolates to find out their extend of variation in morphological and pathogenicity.

\section{Materials and Methods}

\section{Collection of diseased leaf samples}

Diseased leaf samples were collected from nine districts of Bangladesh namely Dhaka, Mymensingh, Rajhhahi, Gazipur, Comilla, Jamalpur, Manikgonj, Jessore, and Faridpur.

These districts are scattered in different geographical locations and climatic conditions (Table 1). Samples were collected in February month from these areas and mainly chemical fungicides were used in these areas to control the disease. The diseased leaves were cut from the plants grown in the field, put into brown paper envelopes and taken to the laboratory, Department of Plant Pathology, Sher-e-Bangla Agricultural University, Dhaka for isolation. The samples were immediately cultured after collection.

\section{Isolation and identification of the pathogen}

The pathogen was isolated by tissue culture method (Ali, 2008). The diseased leaves were cut into pieces ( $4 \mathrm{~mm}$ diameter) and surface sterilization with $\mathrm{HgCl}_{2}$ (1:1000) for 30 seconds. Then the cut pieces were washed in sterile water thrice and dried in keeping untreated blotting paper then placed on to acidified PDA in
Petri dish. The plates containing leaf pieces were incubated at $25^{\circ} \mathrm{C}$ temperature and near ultraviolet light for seven days. When the fungus grew well and sporulated then the pathogen slide was prepared and examined under stereomicroscope (Model: Motic, SMZ-168) and compound microscope (Model: Omano, OMTM85) for identification of the pathogen with the help of relevant literature (CMI Description Vol. No. 338). Pathogenic conidia were muriform, tapering beak and brown in color. After identification of A. porri it was purified for further study in PDA and preserved in refrigerator at $4 \pm 0.5^{\circ} \mathrm{C}$ for further use.

\section{Designation of collected isolates}

The isolates were designated following Aminuzzaman et al. (2010) based on its locations and sources. For example an isolate designated by JMSA 01 represents that this isolate was collected from district- Jessore (J), upazilla- Monirumpur (M), unionShempur (S), village- Aminpur (A) and 01 denotes collection number.

\section{Cultural variability of Alternariaporri}

In cultural variation the colony diameter was measured on the $4^{\text {th }}, 6^{\text {h }}, 8^{\text {th }}, 10^{\text {th }}, 12^{\text {th }}$, and $14^{\text {th }}$ days after inoculation. Growth per day was calculated by the formula:

$\mathrm{Mm} /$ day $=$ (growth observed on a day - growth on previous observation) $/ 2$.

The other cultural properties on colony colour, shape, margin, texture and substrate colour was also recorded.

Table 1. Sample collected area of purple blotch of onion caused by Alternaria porri

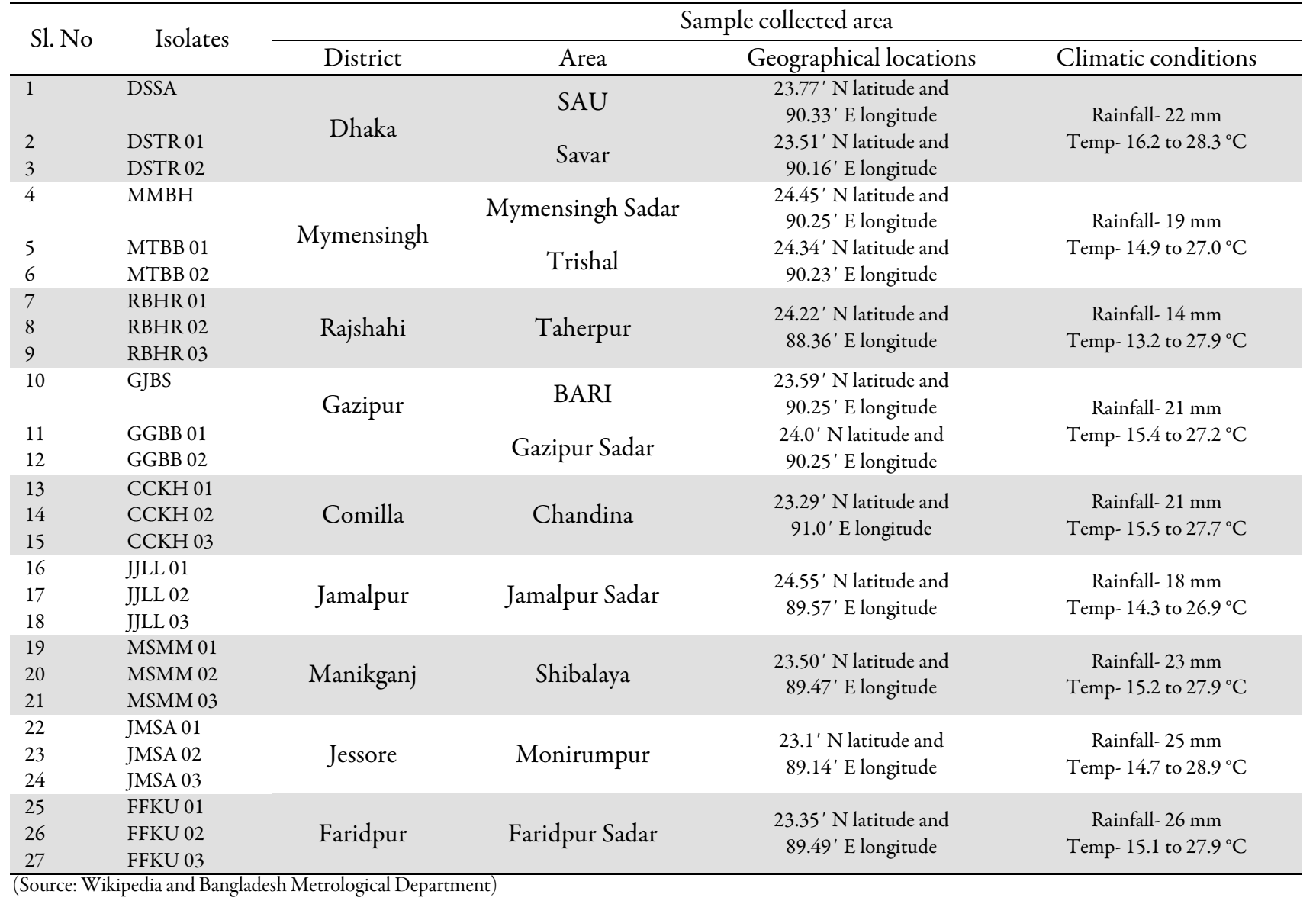


224

\section{Morphological variability of Alternaria porri}

Fifteen (15)-d-old cultures of all the isolates were studied for morphological variations. In terms of conidia colour, shape, size, septation, time of sporulation and number of conidia production were observed on PDA medium. Length and breadth of conidia was measured using digital microscope (Model: Motic, BA-210) and motic software. Twenty conidia per replication were made for the purpose. The conidia produced per unit surface area were estimated using haemacytometer, digital microscope using the formula of Chauhan and Pandey (1995):

Conidia produced per unit surface $=($ No. of conidia $/ \mathrm{ml} \times$ Volume of water of suspension)/(Total surface area of suspension).

\section{Pathogenic variability of Alternaria porri}

For testing the virulence levels of $A$. porri isolates, a local onion cultivar, 'Taherpuri' bulbs were collected from Savar Bazar, Dhaka. Air dried sandy loam soil and cowdung were mixed thoroughly at the ratio of $4: 1$ and filled in earthen pots (20 $\mathrm{cm}$ diameter) in net house following CRD maintaining three replications. The conidia suspension of $A$. porri was prepared with sterilized water using 10 days old PDA culture and the concentration of conidial suspension was adjusted to $21 \times 10^{5}$ per milliliter. The plants were inoculated by 27 isolates of $A$. porri at 30 days after planting. At first the onion leaves were injured by sterile toothpick followed by inoculation of the injured surfaces (one inoculation per leaf) with a drop of inoculums suspension by a micropipette. The inoculated plants were covered with polyethylene bag to maintain high relative humidity $(\% \mathrm{RH})$ and also to prevent natural contamination with other fungal conidia or spores. After 5 days of inoculation, the size of lesions was recorded on $5^{\text {th }}, 7^{\text {th }}, 9^{\text {th }}, 11^{\text {th }}, 13^{\text {th }}, 15^{\text {th }}$, and $17^{\text {th }}$ days. The increase in size of the lesions on day to day basis (mm/day) was estimated by the formula: [leaf infection observed on a day - leaf infection on previous observation/2].

\section{Data analysis}

The collected data were compiled and analyzed statistically using the analysis of variance (ANOVA) technique with the help of a statistical software MSTAT-C (Freed and Scott, 1986) and the mean differences among the treatments were compared by Duncan's Multiple Range Test (Gomez and Gomez, 1986).

\section{Results}

\section{Cultural variation of Alternariaporri}

In respect of cultural characteristics, the isolates of $A$. porri showed variation in growth rate, colony colour, shape, margin and texture and substrate colour. The isolates of $A$. porri depicted variation in growth rate $(\mathrm{mm} /$ day). The maximum increment rate of radial mycelial growth $3.95 \mathrm{~mm}$ per day was recorded in DSTR 02 and the minimum increment rate of radial mycelial growth $2.43 \mathrm{~mm}$ per day was recorded in MMBH (Fig. 1). Among 27 isolates 7 dark olivaceous green, 12 light olivaceous green, 1 greyish white and 7 olivaceous green colony colour isolates were found with 5 irregular, 16 regular with concentric ring and 6 regular without concentric ring shape isolates. Among the isolates 19 entire, 5 irregular and 3 wavy margins with 17 effuse, 1 fluffy and 8 velvety texture were found. Among the isolates 2 grey, 15 deep brown and 10 light brown substrate colour were found (Table 2).

\section{Morphological variation of Alternariaporri}

In respect of morphological characteristics, the isolates of $A$. porri showed variation in conidia production, sporulation, shape and colour of conidia, septation of conidia and size of conidia (Table 3). The highest production of conidia $47.02 \times 10^{3} / \mathrm{mm}^{2}$ was recorded in DSSA and the lowest production of conidia $7.72 \times 10^{3} / \mathrm{mm}^{2}$ was recorded in MMBH (Fig. 2). Highest sporulation time of 11.00 days was recorded in $\mathrm{MMBH}$ and the lowest sporulation time of 3.33 days was recorded in MTBB 01 and MSMM 02. All the isolates produced light to deep brown colour and straight or curved shape conidia. The highest mean horizontal septation 3.56 was recorded in isolate DSSA and the lowest 3.20 in isolate GGBB 01. The highest mean longitudinal septation 1.40 was recorded in isolates DSSA and DSTR 02 whereas the lowest 1.13 in isolates MTBB 02, JJLL 03 and MSMM 03. The highest mean length $28.31 \mu \mathrm{m}$ was recorded in isolate MMBH and the lowest $19.38 \mu \mathrm{m}$ in isolate RBHR 01. The highest mean breadth $8.147 \mu \mathrm{m}$ was recorded in isolate MSMM 01 whereas the lowest $6.740 \mu \mathrm{m}$ in isolate RBHR 03 (Fig. 3).

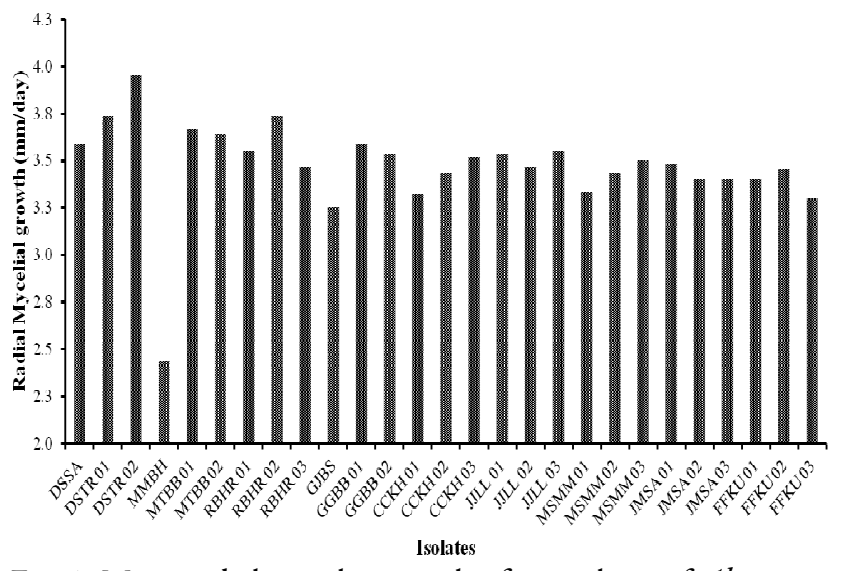

Fig. 1. Mean radial mycelia growth of 27 isolates of Alternaria porri per day

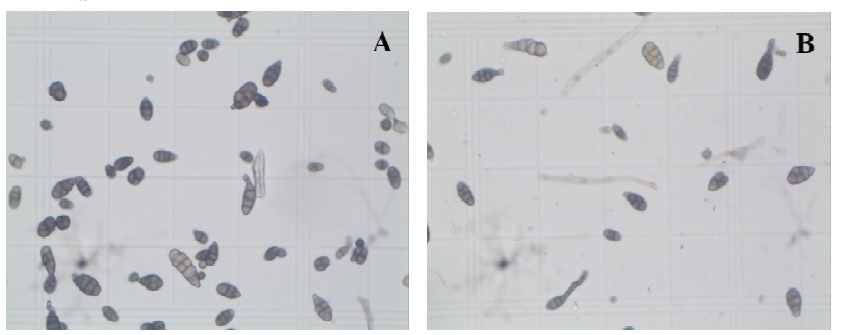

Fig. 2. Counting of Alternaria porri conidia by using haemacytometer and digital microscope; (A) Isolate DSSA (B) Isolate $\mathrm{MMBH}$
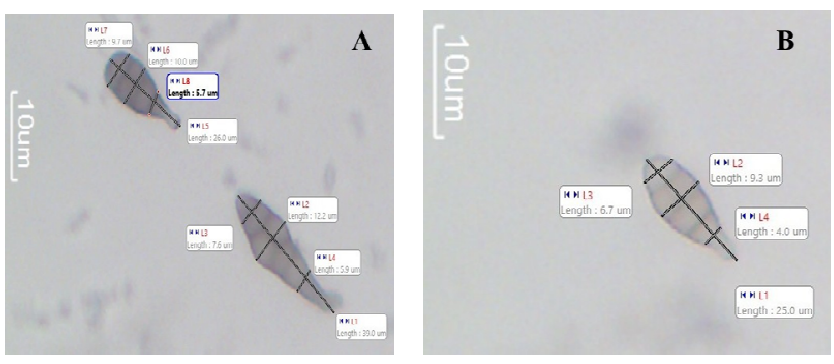

Fig. 3. Measurement of Alternaria porri conidia; (A) Isolate MMBH (B) Isolate RBHR 01 
Table 2. Colony characteristics of 27 Alternaria porri isolates on PDA

\begin{tabular}{ll}
\hline \multicolumn{1}{c}{ Characteristics features } & \multicolumn{1}{c}{ Isolates } \\
\hline Colony colour & DSSA, RBHR 01, GJBS, GGBB 01, GGBB 02, JJLL 01, JMSA 01 \\
$\begin{array}{l}\text { Dark olivaceous green } \\
\text { Grayish white }\end{array}$ & MMBH \\
\hline $\begin{array}{l}\text { Light olivaceous green } \\
\text { Olivaceous green }\end{array}$ & DSTR 01, DSTR 02, RBHR 02, RBHR 03, CCKH 01, CCKH 03, JJLL 02, JMSA 02, JMSA 03, FFKU 01, FFKU 02, FFKU 03 \\
\hline Colony shape & MTBB 01, MTBB 02, CCKH 02, JJLL 03, MSMM 01, MSMM 02, MSMM 03 \\
\hline Irregular & DSSA, DSTR 01, DSTR 02, RBHR 02, RBHR 03, GGBB 01, GGBB 02, CCKH 03, JJLL 01, JJLL 03, MSMM 02, \\
\hline Regular with concentric ring & MSMM 03, JMSA 01, JMSA 02, JMSA 03, FFKU 02 \\
\hline $\begin{array}{l}\text { Regular without concentric } \\
\text { ring }\end{array}$ & MTBB 01, MTBB 02, CCKH 02, MSMM 01, FFKU 01, FFKU 03 \\
\hline Colony margin & DSSA, DSTR 02, MTBB 02, RBHR 02, RBHR 03, GJBS, GGBB 02, CCKH 01, CCKH 02, CCKH 03, JJLL 01, JJLL \\
\hline Entire & 02, JJLL 03, MSMM 02, MSMM 03, JMSA 01, JMSA 03, FFKU 01, FFKU 02 \\
\hline Irregular & DTBB 01, RBHR 01, GGBB 01, JMSA 02, FFKU 03 \\
Wavy & DSTR 01, MMBH, MSMM 01 \\
\hline Colony texture & DSSA, MTBB 01, MTBB 02, RBHR 01, GJBS, GGBB 01, GGBB 02, CCKH 01, CCKH 02, CCKH 03, JJLL 03, JMSA \\
\hline Effuse & 01, JMSA 02, JMSA 03, FFKU 01, FFKU 02, FFKU 03 \\
\hline Fluffy & DMBH \\
\hline Velvet & DSTR 01, DSTR 02, RBHR 02, RBHR 03, JJLL 01, JJLL 02, MSMM 01, MSMM 02, MSMM 03 \\
\hline Substrate colour & MMBH, GJBS \\
\hline Grey & DSSA, MTBB 01, MTBB 02, RBHR 01, RBHR 02, GGBB 01, GGBB 02, CCKH 01, CCKH 02, JJLL 03, JMSA 01, \\
\hline Deep brown & JMSA 02, JMSA 03, FFKU 01, FFKU 03 \\
\hline Light brown & DSTR 01, DSTR 02, RBHR 03, CCKH 03, JJLL 01, JJLL 02, MSMM 01, MSMM 02, MSMM 03, FFKU 02 \\
\hline
\end{tabular}

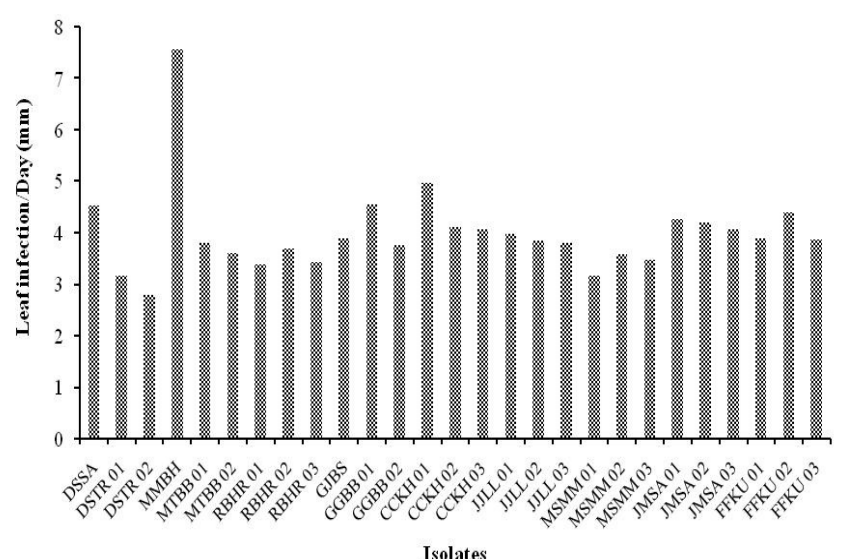

Fig. 4. Mean infection of onion leaf per day by 27 isolates of Alternaria porri

\section{Pathogenic variation of Alternaria porri}

The leaf infection of onion by 27 different $A$. porri isolates varied significantly in the pot experiment. The rate of leaf infection per day maximum increment $7.55 \mathrm{~mm}$ was recorded in isolate MMBH and minimum increment $2.77 \mathrm{~mm}$ was recorded in DSTR02 (Fig.4).

\section{Discussion}

The isolates of $A$. porri depicted variation in growth rate $(\mathrm{mm} /$ day). Isolate DSTR 02 exhibited the fastest growth among the isolates with mean growth rate of $3.95 \mathrm{~mm} /$ day while isolate $\mathrm{MMBH}$ exhibited the slowest growth with mean growth rate of $2.43 \mathrm{~mm} /$ day. Isolates in the present study showed periodic changes in their growth rates. All the isolates showed an increasing trend in growth rate. Sofi et al. (2013) also reported growth rate of $A$. mali isolates 5.86 to $8.21 \mathrm{~mm} /$ day. Goyal et al. (2011) found variation in mycelial growth of thirteen isolates of A. brassicae collected from different geographical zones. Ansari et al. (1989); Patni et al. (2005) and Kaur et al. (2007) found variability in mycelia growth of Alternaria species. Pusz (2009) found colony diameter ranging from 4.8 to $6.8 \mathrm{~cm}$ while working with $A$. alternata. Similar observations were also recorded by Thrall et al. (2005) and Rai and Kumari (2009).

All the isolates varied in colony colour, shape, margin and texture and substrate colour. Colony colour varied from light to dark olivaceous green with greyish white. Mostly the colony was irregular or regular with concentric ring and regular without concentric ring shape with entire, irregular and wavy margin. All the isolates had effuse, fluffy and velvety mycelia growth having grey to brown colour with some variations which were clearly visible from the underside of plates. The results are in agreement with Pusz (2009) who found that the colonies of $A$. alternata isolated from Amaranthus retroflexus varied from light grey to dark grey. Similarly, Rai and Kumari (2009) observed loose, cottony, compact and dense colonies with light to dark black colour in A. alternata infecting Periwinkle. Hubballi et al. (2011) noted variation in the pigmentation of fifteen $A$. alternata isolates producing black, brownish black, greenish black, brown and yellow pigmentation.

In respect of morphological characteristics, the isolates of $A$. porri showed variation in conidia production, sporulation, shape and colour of conidia, septation of conidia and size of conidia.

The conidia production of isolates varied from $7.720 \times 10^{3}$ to $47.02 \times 10^{3}$ per $\mathrm{mm}^{2}$. Similarly, Daniel, et al. (2008) observed $A$. alternata isolates producing $2.8 \times 10^{5}$ to $17.2 \times 10^{5}$ conidia $\mathrm{mL}^{-1}$. In present study, the variation in sporulation time varied in between 11 and 3 days. 
Table 3. Morphological variation of 27 isolates of Alternaria porri

\begin{tabular}{|c|c|c|c|c|c|c|c|c|c|}
\hline \multirow{2}{*}{$\begin{array}{l}\text { Sl. } \\
\text { No }\end{array}$} & \multirow{2}{*}{ Isolate } & \multirow{2}{*}{$\begin{array}{c}\text { Number of } \\
\text { conidia } / \mathrm{mm}^{2} \\
\left(\times 10^{3}\right)\end{array}$} & \multirow{2}{*}{$\begin{array}{l}\text { Sporulation } \\
\text { time (days) }\end{array}$} & \multicolumn{2}{|c|}{ Number of conidial septation } & \multicolumn{2}{|c|}{ Size of conidia } & \multirow{2}{*}{ Shape of conidia } & \multirow{2}{*}{$\begin{array}{l}\text { Colour of } \\
\text { conidia }\end{array}$} \\
\hline & & & & Horizontal & Longitudinal & Length $(\mu \mathrm{m})$ & Breadth $(\mu \mathrm{m})$ & & \\
\hline 1 & DSSA & $47.02 \mathrm{a}$ & $4.00 \mathrm{~b}$ & 3.56 & $1.40 \mathrm{a}$ & $19.91 \mathrm{ij}$ & $7.29 \mathrm{~b}-\mathrm{d}$ & Straight/Curved & Brown \\
\hline 2 & DSTR 01 & $40.40 \mathrm{~b}$ & $3.66 \mathrm{~b}$ & 3.46 & $1.30 \mathrm{ab}$ & $23.20 \mathrm{~d}-\mathrm{g}$ & $7.71 \mathrm{a}-\mathrm{c}$ & Straight & Brown \\
\hline 3 & DSTR 02 & $37.60 \mathrm{bc}$ & $3.66 \mathrm{~b}$ & 3.26 & $1.40 \mathrm{a}$ & $20.45 \mathrm{~h}-\mathrm{j}$ & $7.53 \mathrm{a}-\mathrm{c}$ & Straight & Brown \\
\hline 4 & MMBH & $7.72 \mathrm{j}$ & $11.00 \mathrm{a}$ & 3.36 & $1.26 \mathrm{ab}$ & $28.31 \mathrm{a}$ & $7.33 \mathrm{a}-\mathrm{d}$ & Straight & Deep Brown \\
\hline 5 & MTBB 01 & $34.20 c-e$ & $3.33 \mathrm{~b}$ & 3.26 & $1.23 \mathrm{ab}$ & $19.73 \mathrm{j}$ & $7.57 \mathrm{a}-\mathrm{c}$ & Straight & Brown \\
\hline 6 & MTBB 02 & $32.85 \mathrm{c}-\mathrm{e}$ & $3.66 \mathrm{~b}$ & 3.26 & $1.13 \mathrm{~b}$ & $20.27 \mathrm{~h}-\mathrm{j}$ & $7.63 \mathrm{a}-\mathrm{c}$ & Straight & Brown \\
\hline 7 & RBHR 01 & $27.92 \mathrm{e}-\mathrm{h}$ & $4.33 \mathrm{~b}$ & 3.43 & $1.23 \mathrm{ab}$ & $19.38 \mathrm{j}$ & $7.18 \mathrm{~cd}$ & Straight & Brown \\
\hline 8 & RBHR 02 & $22.83 \mathrm{hi}$ & $3.66 \mathrm{~b}$ & 3.30 & $1.30 \mathrm{ab}$ & $20.90 \mathrm{~h}-\mathrm{j}$ & $7.46 \mathrm{a}-\mathrm{d}$ & Straight & Brown \\
\hline 9 & RBHR 03 & $20.62 \mathrm{i}$ & $3.66 \mathrm{~b}$ & 3.43 & $1.26 \mathrm{ab}$ & $19.82 \mathrm{j}$ & $6.74 \mathrm{~d}$ & Straight & Brown \\
\hline 10 & GJBS & $36.92 \mathrm{~b}-\mathrm{d}$ & $4.33 \mathrm{~b}$ & 3.26 & $1.23 \mathrm{ab}$ & $19.49 \mathrm{j}$ & $7.41 \mathrm{a}-\mathrm{d}$ & Straight & $\begin{array}{l}\text { Light } \\
\text { Brown }\end{array}$ \\
\hline 11 & GGBB 01 & $40.65 \mathrm{~b}$ & $4.00 \mathrm{~b}$ & 3.20 & $1.30 \mathrm{ab}$ & $19.87 \mathrm{ij}$ & $7.27 \mathrm{~cd}$ & Straight & Brown \\
\hline 12 & GGBB 02 & $33.86 \mathrm{c}-\mathrm{e}$ & $3.66 \mathrm{~b}$ & 3.30 & $1.20 \mathrm{ab}$ & $20.13 \mathrm{~h}-\mathrm{j}$ & $7.51 \mathrm{a}-\mathrm{d}$ & Straight & Brown \\
\hline 13 & ССКH 01 & $31.06 \mathrm{~d}-\mathrm{f}$ & $4.00 \mathrm{~b}$ & 3.26 & $1.23 \mathrm{ab}$ & $24.55 \mathrm{~cd}$ & $7.67 \mathrm{a}-\mathrm{c}$ & Straight/Curved & Brown \\
\hline 14 & CCKH 02 & $25.55 \mathrm{f}-\mathrm{i}$ & $4.00 \mathrm{~b}$ & 3.26 & $1.20 \mathrm{ab}$ & $22.15 \mathrm{e}-\mathrm{h}$ & $7.68 \mathrm{a}-\mathrm{c}$ & Straight & Brown \\
\hline 15 & ССКH 03 & $25.46 \mathrm{f}-\mathrm{i}$ & $3.66 \mathrm{~b}$ & 3.26 & $1.20 \mathrm{ab}$ & $21.40 \mathrm{f}-\mathrm{j}$ & $7.45 \mathrm{a}-\mathrm{d}$ & Straight & Brown \\
\hline 16 & JJLL 01 & $33.61 \mathrm{c}-\mathrm{e}$ & $4.00 \mathrm{~b}$ & 3.40 & $1.20 \mathrm{ab}$ & $27.23 \mathrm{ab}$ & $8.13 \mathrm{a}$ & Straight & Brown \\
\hline 17 & JJLL 02 & $30.55 \mathrm{e}-\mathrm{g}$ & $3.66 \mathrm{~b}$ & 3.23 & $1.23 \mathrm{ab}$ & $23.46 \mathrm{~d}-\mathrm{f}$ & $7.70 \mathrm{a}-\mathrm{c}$ & Straight & Brown \\
\hline 18 & JJLL 03 & $29.11 \mathrm{e}-\mathrm{h}$ & $3.66 \mathrm{~b}$ & 3.26 & $1.13 \mathrm{~b}$ & $22.05 \mathrm{e}-\mathrm{i}$ & $7.69 a-c$ & Straight & Brown \\
\hline 19 & MSMM 01 & $23.93 \mathrm{hi}$ & $4.00 \mathrm{~b}$ & 3.23 & $1.26 \mathrm{ab}$ & $26.24 b c$ & $8.14 \mathrm{a}$ & Straight & Brown \\
\hline 20 & MSMM 02 & $23.00 \mathrm{hi}$ & $3.33 \mathrm{~b}$ & 3.36 & $1.16 \mathrm{~b}$ & $23.09 \mathrm{~d}-\mathrm{g}$ & $7.91 \mathrm{a}-\mathrm{c}$ & Straight/Curved & Deep Brown \\
\hline 21 & MSMM 03 & $23.26 \mathrm{hi}$ & $4.00 \mathrm{~b}$ & 3.33 & $1.13 \mathrm{~b}$ & $21.18 \mathrm{~g}-\mathrm{j}$ & $7.80 \mathrm{a}-\mathrm{c}$ & Straight & Brown \\
\hline 22 & JMSA 01 & $25.03 \mathrm{f}-\mathrm{i}$ & $3.66 \mathrm{~b}$ & 3.43 & $1.20 \mathrm{ab}$ & $25.74 \mathrm{bc}$ & $8.09 \mathrm{ab}$ & Straight & Brown \\
\hline 23 & JMSA 02 & $23.42 \mathrm{hi}$ & $3.66 \mathrm{~b}$ & 3.23 & $1.16 \mathrm{~b}$ & $23.59 \mathrm{de}$ & $7.84 \mathrm{a}-\mathrm{c}$ & Straight & $\begin{array}{l}\text { Light } \\
\text { Brown }\end{array}$ \\
\hline 24 & JMSA 03 & $25.89 \mathrm{f}-\mathrm{i}$ & $4.00 \mathrm{~b}$ & 3.33 & $1.20 \mathrm{ab}$ & $23.54 \mathrm{~d}-\mathrm{f}$ & $7.67 \mathrm{a}-\mathrm{c}$ & Straight & Brown \\
\hline 25 & FFKU 01 & $24.44 \mathrm{~g}-\mathrm{i}$ & $4.00 \mathrm{~b}$ & 3.26 & $1.20 \mathrm{ab}$ & $22.12 \mathrm{e}-\mathrm{h}$ & $7.54 \mathrm{a}-\mathrm{c}$ & Straight/Curved & Brown \\
\hline 26 & FFKU 02 & $24.61 \mathrm{f}-\mathrm{i}$ & $4.00 \mathrm{~b}$ & 3.30 & $1.16 \mathrm{~b}$ & $21.27 \mathrm{~g}-\mathrm{j}$ & $7.17 \mathrm{~cd}$ & Straight & Brown \\
\hline \multirow[t]{3}{*}{27} & FFKU 03 & $26.22 \mathrm{f}-\mathrm{i}$ & $4.00 \mathrm{~b}$ & 3.30 & $1.30 \mathrm{ab}$ & $20.43 \mathrm{~h}-\mathrm{j}$ & $7.28 \mathrm{~b}-\mathrm{d}$ & Straight & Brown \\
\hline & Significance & ** & ** & ns & * & ** & * & & \\
\hline & $\mathrm{CV}(\%)$ & $11.68 \%$ & $20.47 \%$ & $5.85 \%$ & $8.51 \%$ & $5.09 \%$ & $5.38 \%$ & & \\
\hline
\end{tabular}

(ns- non significant, ${ }^{*}$-significant at $\mathrm{P}=0.05,{ }^{* *}$-significant at $\mathrm{P}=0.01$. Different lowercase letters beside the mean value indicate significant at $\mathrm{P}=0.05$ or 0.01 )

All the isolates produced light to deep brown colour and straight or curved shape conidia. Similarly, Kaul and Saxena (1988) observed differences in colour, shape and sporulation of the isolates of $A$. solani. Goyal et al. (2011) reported variation in sporulation of thirteen isolates of $A$. brassicae collected from different geographical zones. Ansari et al. (1989); Patni et al. (2005) and Kaur et al. (2007) found variability in sporulation of Alternaria species. Conidial septation both horizontal and longitudinal varied significantly among the isolates. Horizontal septa varied from 3 to 6 and longitudinal septa from 1 to 2 . The highest mean number of horizontal septa was 3.56 whereas the lowest was 3.20. The highest mean number of longitudinal septa was 1.40 and the lowest 1.13 . In present study, the average conidial size varied from $11.20-39.20 \times 4.76-$ $11.43 \mu \mathrm{m}$. Sofi et al. (2013) reported that average conidial size ranged from 21.36 to $31.74 \times 8.34$ to $14.48 \mu \mathrm{m}$. Rotem (1966) found a wide variability in the spore dimensions of 42 isolates of $A$. solani.

A considerable pathogenic variability was observed in size of leaf infection among the isolates. The maximum leaf infection rate was $7.55 \mathrm{~mm} /$ day while minimum $2.77 \mathrm{~mm} /$ day. Isolates in the present study depicted periodic changes in their leaf infection rates. All the isolates showed an increasing trend in leaf infection rate from 5 days to 17 days. The findings are in agreement with Thrall et al. (2005) who reported significant variations in the lesion size produced by $A$. brassicicola isolates on wound inoculated Cakile maritima plants. Kumar (2004) also reported variation in lesion size and lesion number in A. triticina isolates. However, present observations are contradictory to the findings of Quayyum et al. (2005) who did not find any significant variation in the lesions produced by the isolates of $A$. panax on detached leaflets of ginseng.

\section{Conclusion}

All the isolates showed variation in terms of cultural, morphological and pathogenic characteristics. Significant variation in growth, sporulation and conidial morphology of $A$. porri isolates were found on PDA media irrespective of crop and geographical states. All the isolates were found pathogenic in nature against their respective host. The fungal isolates showed substantial identities with $A$. porri and further detailed variation and diversity can be studied at molecular level. This could help us to reveal the true nature of this fungus from Bangladesh and proper sustainable management for purple blotch of onion disease can be implemented. 


\section{References}

AIS (2011).KrishiDiary. DAE, Khamar Bari, Dhaka.

Ali MH (2008). Control of purple blotch complex of onion through fertilizer and fungicide application. MS Thesis, Department of Plant Pathology, Sher-e-Bangla Agricultural University.

Aminuzzaman FM, Hossain I, Ahmed F (2010). Cultural variation and pathogenicity of Bipolaris sorokiniana on wheat in Bangladesh. International Journal of Agriculture, Environment and Biotechnology 3(1):76-81.

Ansari NA, Khan MW, Muheet A (1989). Effect of some factors on growth and sporulation of Alternaria brassicae causing Alternaria blight of rapeseed and mustard. Acta Botanica Indica 17:49-53.

Ashrafuzzaman MH, Ahmed MU (1976). Control of foliage disease of onion by spray fungicides. Bangladesh Journal of Horticulture 4(2):2530.

BBS (2012). Year Book of Agricultural Statistics of Bangladesh, 2009-10. Statistics Division, Ministry of Planning, Dhaka.

Chakraborty M, Quddus T, Rahman S, Azad MAK, Hossain MR, Hoque A, Saha MK, Haque MA (2015). Molecular characterization of selected mutant lines of onion (Allium cepa $\mathrm{L}$.) against purple leaf blotch disease using SSR markers. American Journal of Experimental Agriculture $8(4): 261-267$.

Chauhan S, Pandey BN (1995). Identification of Bipolaris maydis race T pathogenic to Populus deltoids. Indian Phytopathology 48(1):55-60.

Daniel DCC, Eduardo A, Tereza RSB, Renato BC, Eloisa AGIL (2008). Comparison of methodologies for conidia production by Alternaria alternate from citrus. Brazilian Journal of Microbiology 39:792-798.

FAO (2008). Production Year Book. Rome, Italy.

FAO (2012). Production Year Book for 1990. Food and Agriculture Organization, Rome.

Freed RD, Scott DE (1986). MSTATC Crop and Soil Science Department, Michigan State University, MI, USA.

Gomez KA, Gomez AA (1986). Statistical Procedure for Agricultural Research ( $2^{\text {nd }}$ edn.). International Rice Research Institute, A WilleyInter-Science, Publication pp.28-192.

Goyal P, Chahar M, Mathur AP, Kumar A, Chattopadhyay C (2011). Morphological and cultural variation in different oilseed Brassica isolates of Alternaria brassicae from different geographical regions of India. Indian Journal of Agricultural Sciences 81(11):1052-1058.

Hossain M, Chowdhury MN, Khan AL (1993). Effect of fungicides on the production of healthy onion seeds. Abstract of Fifth Biennial Conference, Bangladesh Phytopathological Society.

Hubballi M, Sornakili A, Nakkeeran S, Anand T, Raguchander T (2011). Virulence of Alternaria alternata infecting noni associated with production of cell wall degrading enzymes. Journal of Plant Protection Research 51:87-92.

Islam MS (2006). Effect of bion in controlling purple blotch and storage diseases of onion. MS Thesis, Department of Plant Pathology, Bangladesh Agricultural University.

Islam MR, Akter N, Chowdhury SM, Ali M, Ahamed KU (2001). Evaluation of fungicides against Alternaria porri causing purple blotch of onion. Journal of Agricultural Science and Technology 2(1):27-30.
Kaul AK, Saxsena HK (1988). Physiological specialization in Alternaria solani causing early blight of tomato. Indian Journal of Mycology and Plant Pathology 18:128-132.

Kaur S, Singh G, Banga SS (2007). Documenting variation in Alternaria brassicae isolates based on conidial morphology, fungicidal sensitivity and molecular profile. Proceedings of the $12^{\text {th }}$ International Rapeseed Congress, 26-30 March, Wuhan, China 4:87-89.

Kumar A (2004). Cultural and physiological variability among the isolates of Alternaria triticina from Bihar causing leaf blight of leaf. Plant Disease Research 19:10-15.

Pascua MSC, Kik-Patena LS, Badar AJ (1997). Breeding for purple blotch resistant in garlic and shallot. Philippine Journal of Crops Science 5:7275.

Patni CS, Kolte SJ, Awasthi RP (2005). Cultural variability of Alternaria brassicae, causing Alternaria blight of mustard. Annals of Plant Physiology 19:231-242.

Purseglove JW (1972). Tropical Crops (Monocotyledons-1). Longman, London pp 32-35.

Pusz W (2009). Morpho-physiological and molecular analyses of Alternaria alternata isolated from seeds of Amaranthus. Phytopathology 54:5-14.

Quayyum HA, Dobinson KF, Traquair JA (2005). Conidial morphology, virulence, molecular characterization and host-parasite interactions of selected Alternaria panax isolates on American ginseng. Canadian Journal of Botany 83:1133-1143.

Rahman ML, Ahmed HU, Mian IH (1988). Efficacy of fungicides in controlling purple leaf blotch of onion. Bangladesh Journal of Plant Pathology 4(1-2):71-76.

Rahman ML (1990). Efficacy of fungicides in controlling purple leaf blotch (Alternaria porri) of onion (Allium cepa). MS Thesis, Department of Plant Pathology, Sher-e-Bangla Agricultural University.

Rai PK, Kumari L (2009). Variability in Alternaria alternata infecting periwinkle(Catharanthus roseus). Progress in Agriculture 9:269-272.

Rotem J (1966). Variability in Alternaria porri f.sp. solani. Israel Journal of Botany 15:47-57.

Schwartz HF ( 2010). Soil borne diseases of onion. Colorado State University Extension Service.

Sofi TA, Beig MA, Dar GH, Ahmad M, Hamid A, Ahangar FA, Padder BA, Shah MD (2013). Cultural, morphological, pathogenic and molecular characterization of Alternaria mali associated with Alternaria leafblotch of apple. African Journal of Biotechnology 12(4):370-381.

Thind TS, Jhooty JS (1982). Association of trips with purple blotch infection on onion plants caused by Alternaria porri. Indian Phytopathology 35:696-698.

Thrall PH, Barrett LG, Burdon JJ, Alexander HM (2005). Variation in pathogen aggressiveness within a metapopulation of the Cakile maritime - Alternaria brassicicola host-pathogen association. Plant Pathology 54:265-274. 